IZA DP No. 5856

Growth, Colonization, and Institutional Development: In and Out of Africa

Graziella Bertocchi

July 2011 


\title{
Growth, Colonization, and Institutional Development: In and Out of Africa
}

\author{
Graziella Bertocchi \\ University of Modena and Reggio Emilia, \\ CEPR, CHILD and IZA
}

Discussion Paper No. 5856

July 2011

IZA

P.O. Box 7240

53072 Bonn

Germany

Phone: +49-228-3894-0

Fax: +49-228-3894-180

E-mail: iza@iza.org

Any opinions expressed here are those of the author(s) and not those of IZA. Research published in this series may include views on policy, but the institute itself takes no institutional policy positions.

The Institute for the Study of Labor (IZA) in Bonn is a local and virtual international research center and a place of communication between science, politics and business. IZA is an independent nonprofit organization supported by Deutsche Post Foundation. The center is associated with the University of Bonn and offers a stimulating research environment through its international network, workshops and conferences, data service, project support, research visits and doctoral program. IZA engages in (i) original and internationally competitive research in all fields of labor economics, (ii) development of policy concepts, and (iii) dissemination of research results and concepts to the interested public.

IZA Discussion Papers often represent preliminary work and are circulated to encourage discussion. Citation of such a paper should account for its provisional character. A revised version may be available directly from the author. 
IZA Discussion Paper No. 5856

July 2011

\section{ABSTRACT \\ Growth, Colonization, and Institutional Development: In and Out of Africa*}

This essay investigates the determinants of the growth performance of Africa. I start by illustrating a broader research agenda which accounts not only for basic economic and demographic factors, but also for the role of history and institutional development. After reporting results from standard growth regressions, I analyze the role of Africa's peculiar history, which has been marked by its colonization experience. Next I discuss the potential growth impact of state fragility, a concept which reflects multiple facets of the dysfunctions that plague the continent. The last topic I address is the influence, in and out of Africa, of the slave trades. The essay ends with critical conclusions and suggestions for further research.

JEL Classification: $\quad$ O43, N17, H11

Keywords: growth, Africa, history, colonization, institutions, state fragility, slavery

Corresponding author:

Graziella Bertocchi

Università degli Studi di Modena e Reggio Emilia

Dipartimento di Economia Politica

Viale Berengario 51

41100 Modena

Italy

E-mail: graziella.bertocchi@unimore.it

\footnotetext{
I would like to thank Olivier de la Grandville and Arcangelo Dimico for helpful comments and suggestions. Generous financial support from Fondazione Cassa Risparmio di Modena is gratefully acknowledged.
} 


\section{Introduction}

One of the most challenging questions for modern growth theory is why Africa has been underperforming for the entire post-war period, and probably even before, if compared with the rest of the world. This fact remains true even though, following a long sequence of disastrous decades, the economic conditions of some African countries have shown a rapid improvement since the mid-1990s (Sala-i-Martin et al., 2010; Young, 2010).

There is a growing literature which has tried to document and understand the African experience. An initial research line has attempted to compare Africa, as a whole, with the rest of the world. For a cross section of countries, Barro (1991) shows that a dummy for sub-Saharan Africa exerts a significant and negative effect on the average growth of per-capita GDP for the 1960-1985 period, after controlling for a broad set of growth correlates. In the same vein, some progress towards a deeper understanding of the area's specific problems is made by Easterly and Levine (1997), who highlight the potential role of ethnic diversity, by Schmidt-Hebbel (1996), who focuses on fiscal policies, and by Sachs and Warner (1997), who emphasize the impact of geography.

One limit of the continent dummy approach is that it can only assess how Africa as a whole, or its subSaharan portion, differ from the rest of the world, thus obscuring important heterogeneities within the continent itself. Thus, a parallel line has attempted instead to emphasize specific cross-country differences within African samples. The purpose of this essay is to illustrate the main results so far reached within this stream of the literature. Rather than at a complete survey, my goal is to offer a reconstruction of the path followed by this largely empirical exploration and of its main turning points. 
Moreover, I explain how research on the empirics of growth in Africa is inspired by a broader agenda which has focused on the links among growth, history, and institutions.

The essay is organized as follows. Section 2 briefly describes the general research agenda on growth, history, and institutions. Section 3 investigates the role of standard determinants of Africa's specific growth performances. Section 4 focuses on those historical factors that are particularly important for Africa, being determined by the history of the continent's colonization. Section 5 introduces the latest addition to the never ending list of candidate growth correlates, the concept of state fragility, and reviews its potential impact. Section 6 addresses the long term influence on development, in and out of Africa, of the slave trades. Section 7 derives critical conclusions and indicates directions for further research.

2. Growth, history, and institutions

The present investigation on the determinants of growth in Africa is an ideal application of a broader research agenda which has developed in recent years around the combination of three main ingredients: the economics of growth, the theory of institutions, and their interrelationship with history.

The revival of growth theory during the 1980s, building on Solow's (1956) seminal contribution, is where this research line finds its deepest roots. Romer (1986) and Lucas (1988) are the first to adapt the Solowian model by embedding endogenous technical progress and human capital, with the goal of comprehending the post-war persistence of cross-country differences in growth performances. 
At the same time, the field of development economics, by then largely merged with macroeconomic dynamics, has come to recognize the crucial role of history in shaping a country's destiny. Extended data collection, as a joint effort of economists, economic historians and historians (Maddison, 2007), has broadened the time horizon for empirical investigations over a longer and longer time span, thus allowing researchers to answer old questions and also to raise new ones. On the modeling front, an influential literature has investigated the determinants of growth over the long run, in order to find a unified explanation of very different phases of the history of human development, going back to the Malthusian era and even beyond (Galor, 2011).

At the same time, extending the relevant time horizon backward has allowed economists to recognize an increasing role for institutional factors, besides purely economic ones. Indeed the historical and institutional dimensions complement each other, since the economic impact of institutions tends to manifest itself more clearly in the long run. Building on the earlier intuition by North (1981), a broad set of institutions has entered the research agenda. Just to name a few contributors, Engerman and Sokoloff (1997) highlight the links among factor endowments, institutions, and differential growth paths. La Porta et al. (1998) start a research line on the effects of legal institutions on various outcomes. Barro (1999) extends the growth regressions approach to the study of the links between growth and democracy. Acemoglu et al. (2004) point to institutions as the fundamental cause of long run growth.

As explained in Bertocchi (2006), the case of Africa is especially promising as an application of the research line that combines growth, history and institutions, since the colonial institutions established in Africa mainly during the nineteenth century are likely to have shaped, directly and indirectly, the development of the area. Fenske (2011) provides a review essay on the role of institutions in African 
history and development and argues that even crucial growth factors such as geography, ethnic fractionalization and colonial history operate largely through institutions. Nunn (2009) also provides a survey of the line of research on history and development, with a special focus on colonial rule as a unifying theme.

\section{Growth in Africa}

As previously explained, my main focus is on the differential growth performances within Africa. Among growth determinants, I start by discussing standard economic factors. Rodrik (1999) is among the first to adopt the growth regressions approach for a sample of African countries. With the goal of understanding the specific impact of trade policy, he replicates the specification chosen by Sachs and Warner (1997) for a sample of sub-Sahara African countries over the 1965-90 period. The dependent variable is per capita growth and the explanatory variables preliminarly considered are initial per capita income, dummies for tropical climate and landlocked countries, life expectancy, public savings, institutional quality, measures of openness, and population growth. A more parsimonious specification that accounts for limited data availability shows a significant effect of initial per capita income, life expectancy, public savings, population growth, and export taxation. Thus, he establishes that even within sub-Saharan Africa there is evidence of convergence, while growth differentials are explained by a combination of human resources and macroeconomic policy. These findings are broadly in line with standard predictions from growth theory, suggesting that the sources of underdevelopment in subSaharan Africa are not specific to this region. However, the same exercise repeated over three subperiods (1964-74, 1975-84, and 1985-94) reveals a much worse fit of each regression and a loss of significance of trade policy and demographics. This suggests that over shorter horizons growth rates 
tend to be unstable and that their determinants may vary over time, more widely in Africa if compared with the rest of the world.

Another attempt to measure growth within Africa is presented by Bertocchi and Canova (2002), who adapt the benchmark growth regressions initially proposed by Barro (1991). Over the 1960-88 period, they select a specification including the combination of economic and sociopolitical variables which displays the best explanatory power for average growth of per capita income for a cross section of African countries. Such a combination includes the initial condition (and its square), the investmentoutput ratio, the percentage of working age population in secondary school, the index of political rights, the index of ethnic fractionalization, and a dummy for oil producing countries. As in Rodrik (1999), in the full sample these variables tend to be associated with significant coefficients with the expected sign. However, over sub-periods, once again the picture varies considerably: in the 1960-1973 sample only investment matters, while only the index of ethnic fractionalization is significant in the 1974-1980 sample, and very little significance is left in the final 1981-1988 sample. This non-robustness denies the existence of a single cause for Africa's poor growth performance over the period under consideration and suggests that different factors may matter for subsequent stages of development. In the initial stage investment in physical capital appears to be the most important driver, while later on human capital accumulation and political rights emerge as crucial for growth. Bertocchi and Guerzoni (2011) produce updated evidence on the growth performance of the area by running comparable growth regressions over a yearly 1999-2004 panel. They find a tendency to convergence and that economic development is facilitated by schooling and government expenditures, while it is retarded by inflation and ethnic fractionalization. Over this time frame, the relationship between civil liberties and growth is non-linear, suggesting higher growth for intermediate regimes, even though with marginal statistical significance. 
In all the investigations reported above, geographical variables such as latitude and a dummy for landlocked countries, which usually matter in a world context, turn out not to contribute to the understanding of the local growth experience, possibly because they exhibit limited regional variation.

To conclude, while the analysis of standard growth factors does confirm, for Africa, conditional convergence, at the same time the influence of regressors other than the initial condition tends to vary significantly across samples, leading to unsatisfactory results that suggest a potential role for omitted variables.

\section{History and colonization}

The conclusion from the previous section is that standard growth determinants, even those reflecting current institutional characteristics, cannot provide a complete and robust description of the African case. One of the most promising avenues undertaken by subsequent research has been to gauge the potential impact of the history of the continent, with special emphasis on its colonization experience. The basic conjecture behind this avenue is that colonization may be the reason both for low average growth rates in Africa and, at the same time, for the observed heterogeneities across African countries. Africa represents a particularly appropriate setting to analyze the impact of colonial rule on growth because, historically, nowhere else was colonization so far-reaching and time-homogeneous in nature as in the African experience that began at the end of the nineteenth century, despite significant differences across individual countries and colonization regimes. The prevailing wisdom from the previous, huge literature outside of economics was that colonization was bad for colonial economies. According to the drain of wealth thesis, most of the colonial surplus was extracted by the metropolitan 
countries. Exploitation also distorted the colonial economies in many ways, by reducing physical and human capital accumulation and by generating dysfunctional institutions. An alternative point of view emphasizes instead the positive modernization impulses that came from the metropolises and the advantages deriving from the integration of the colonies into the world economic system. Within the economic literature, Lucas (1990) and Grossman and Iyigun (1995) develop static models of colonial domination, while early empirical contributions are represented by La Porta et al. (1998), who focus on the legal origins associated with colonial heritage; Alam (1994), who compares the growth rates of sovereign countries and colonies, but with the exclusion of Africa; and Grier (1999), who studies the relationship between the length of colonial rule and growth.

For the 1960-88 period, Bertocchi and Canova (2002) explore the empirical relevance of colonial variables for a sample of African countries within a standard growth regressions framework. To overcome the obstacle of data availability for the colonial period proper, they employ post-war data and historical information to identify the consequences of colonial domination for current performances. To this end, they classify African countries according to a number of indicators: their political status (i.e., colony vs. dependency vs. independent country) during the colonial period; their metropolitan ruler during domination; and the degree of economic penetration they were exposed to, as captured by the ratio of GNP to GDP at the end of the colonial period. Controlling for standard determinants, they find that in Africa the identity of the metropolitan ruler and economic penetration do add explanatory power in cross-sectional growth regressions. Namely, British colonies have superior growth performances if compared with the former colonies of France, Italy, and Portugal, while higher economic penetration is detrimental. Moreover, the colonial indicators are correlated with measures of human capital accumulations and political distortions. Hence, several decades after the end of colonization, its legacy still exerts a significant impact on growth in Africa, both directly and indirectly. These results support 
the conjecture that colonial rule may indeed represent the omitted factor behind the relationship between local average growth rates and economic and sociopolitical factors. While the above conclusions are based on cross-country data for the 1960-88 period, Bertocchi and Guerzoni (2011) review the evidence over a yearly 1999-2004 panel, to find that colonial indicators no longer contain any explanatory power, which suggests that the lasting influence of the colonial era may finally have faded in more recent times.

An influential related research line that has also developed around the issue of colonization is based on the original contribution by Acemoglu et al. (2001). With the more general goal of establishing the importance of institutions for current development, they identify in colonial history an instrument for institutions which can address their potential endogeneity. Indeed reverse causation becomes a crucial issue when taking into account institutional variables, since the direction of causality with respect to income and growth is by no means obvious. They focus on a specific variable, the mortality rate of the initial settlers, about which they collect and compile information based on detailed historic sources. Settler mortality is exploited as an instrument for current institutions, by arguing that colonizers adopted very different policies in places with different mortality rates. In places where they faced high mortality, they could not settle and were therefore more likely to set up extractive institutions, which in turn persist in present times. Their two-stage least-squares estimates establish that institutions, and in particular the degree of property rights protection, do affect economic development. In the previously mentioned papers based on growth regressions, the potential for endogeneity is addressed indirectly by Bertocchi and Canova (2002), who employ predetermined explanatory variables dated at the beginning of the sample period, and directly by Bertocchi and Guerzoni (2011), who instrument with its lag the only variable for which they find evidence of endogeneity, i.e., government expenditure over GDP. For the sake of comparison between the two parallel streams of the literature on colonization, it should be 
also noticed that Acemoglu et al. (2001), because of the way their instrumental variable is generated, can only include former colonies in their sample. Moreover, they do not focus exclusively on Africa. Finally, they do not distinguish, as Bertocchi and Canova (2002) do, between colonies and dependencies, even though to some extent it could be argued that at least within Africa dependencies were established in lower mortality places.

Another related stream of the literature has gone even beyond the colonial period to discover the roots of current performances. Indeed one cannot exclude a role for long term factors that predate colonial domination. Examples are the following. Herbst (2000) points to the underdevelopment of pre-colonial polities. Bockstette et al. (2002) establish a link between state antiquity, a measure of the depth of experience with state level institutions, and institutional quality. Gennaioli and Rainer (2007) uncover for Africa a positive association between stronger pre-colonial political institutions and public goods provision. Michalopoulos and Papaioannou (2010) show that tribal pre-colonial political institutions and class stratification still exert an effect on local economic activity in Africa, which they measure using satellite data on light density at night following Henderson et al. (2010). Finally, Nunn (2008a) studies the impact of the slave trades, while Nunn and Puga (2010) focus on the historic interaction between terrain ruggedness and Africa's slave trades, i.e., between geography and institutions. In Section 6 I return to the issue of the slave trades in more detail.

More recently, micro-level data have also been exploited, with an even more precise focus on single African countries or specific sub-regions. One example of this line of research is Huillery (2009), who employs household surveys data on French West Africa to produce evidence that early colonial investments had large and persistent effects on current outcomes. 
While the literature described so far is empirical, a few efforts have been made to model the underlying causal relationships within a dynamic setting. Bertocchi (1994) explicitly introduces colonization into a standard growth model with overlapping generations, in order to determine the net effect of modernization and the drain of wealth on the colonial economy. Colonization is modeled in the form of restrictions on direct foreign investment and exploitative activities, which may induce permanent distortions to physical and human capital accumulation and thus lead to negative growth rates even after decolonization. Nunn (2007) develops a game-theoretic model with multiple equilibria, only one of which is associated with secure property rights and a high level of production. In this setting, external extraction may drive a society into a low production equilibrium. Since this equilibrium is stable, the society remains trapped into it even after external extraction ends. Both models thus provide an explanation for the lasting legacy of colonial rule.

Summing up, colonial history has been shown to matter for growth in Africa, in a number of dimensions, but its influence has not been captured by a single explanatory variable which can identify the impact of colonization. Moreover, its effect appears to have faded over time, while the region is still underperforming. This implies that even accounting for colonial history does not yet provide a complete and consistent answer to the question about the determinants of African growth.

\section{State fragility}

The concept of state fragility (from now on, fragility) is perhaps the most recent newcomer to the debate about growth in Africa. Rather than to specific economic, institutional, or historical characteristics, the condition of fragility has been associated with combinations of multiple dysfunctions, including a country's inability to provide vital services, unstable and weak governance, 
persistent and extreme poverty, lack of territorial control, and high propensity to conflict and civil war. It is clear, however, that these dysfunctions can in turn be determined by repeated interactions across a number of factors over the long run. While it may be difficult to isolate the influence of each of these factors singularly, using a composite measure may facilitate the analysis.

Once again, Africa has played a central role in the analysis of fragility, since it is in this continent that fragility is especially widespread. Indeed the European Report on Development (2009) is entirely devoted to the problem of fragility in Africa. The potential growth impact of fragility and the consequent relevance of fragility for policy are also confirmed by the increasing attention of other international organizations. The 2011 World Development Report (World Bank, 2011) focuses on conflict countries. Development practitioners, such as the Government and Social Development Resource Centre (2010), also warn policymakers about the need to understand and respond to fragile situations.

One of the most widely used definitions of fragility is based on the Country Policy and Institutional Assessment (CPIA) which has been conducted by the World Bank since 1999. The ratings are intended to capture the quality of a country's policies and institutional arrangements, with a focus on the key elements that are within the country's control, rather than on outcomes (such as growth rates) that are also influenced by elements outside the country's control. Since the CPIA ratings represent criteria for aid allocation, they carry huge practical implications for policy. On the basis of the CPIA, the World Bank defines as fragile those low-income countries scoring 3.2 and below (over a 1-6 range). From 1999 to 2005, the individual ratings have been kept confidential. However, the general rankings of countries have been made public. On the basis of the rankings, it is therefore possible to infer the distribution of the countries by quintile. On the basis of the resulting quintile distribution, the OECD 
defines as fragile those countries in the bottom two quintiles, as well as those which are not rated. There is a partial overlap between the CPIA-based definitions of fragility and other related indexes, such as the Failed State Index (published by the Fund for Peace), the Index of State Weakness (published by the Brookings Institution), the indicator of Failed \& Fragile States (published by the Country Indicators for Foreign Policy project), and the Fragility States Index (published by Polity IV). While all these indicators record similar components, the choice of variables and their weighting schemes remain largely arbitrary.

There is a small but expanding literature on the link between fragility and development in Africa. Bertocchi and Guerzoni (2011) employ the OECD definition of fragility within a yearly panel dataset covering sub-Saharan Africa in the 1999-2004 period. Following the benchmark specification of Barro (1991) and Bertocchi and Canova (2002), they include in their growth regressions an initial condition for per capita income and a wide range of economic, demographic, geographic, and institutional factors. Their results indicate that the conventional measure of fragility employed by the OECD exerts no effect on economic development, once standard regressors are accounted for. However, when they apply a more severe definition of fragility, which only includes the countries in the bottom quintile, they find a clear, negative impact of this condition, even after controlling for endogeneity through instrumental variables estimation. Using a comparable sample and the OECD conventional definition, Baliamoune-Lutz (2009) highlights how fragility exerts a non-linear impact on per capita income and that it tends to interact with several other factors: in fragile countries, beyond a threshold level trade openness may actually be harmful to income, while small improvements in political institutions can have adverse effects. Fosu (2009) explores the growth impact of policy syndromes, which include among other components state breakdown, a concept which is in turn close to fragility since it refers to a condition involving civil wars and acute political instability (see Fosu and O’Connell, 2006, for a 
definition of policy syndromes). His findings are that the absence of policy syndromes encourages growth in Africa.

The potential endogeneity of fragility is a serious concern, which has been addressed by Bertocchi and Guerzoni (2010) by gauging the links between fragility and other standard growth determinants. They find that indeed, within Africa, fragility tends to be shaped by institutional development, a conclusion which questions its exogeneity. In particular, the probability of a country having a fragile state appears to decrease with the level of civil liberties and to increase with the number of revolutions, while economic factors do not matter. These findings differ sharply from those presented by Carment et al. (2008) for a world sample, over which per capita income appears to be the main driver of fragility. This radically different conclusion can be explained, once again, by the specificity of the African region, but also by the fact that the former study employs the OECD definition of fragility, while the latter employs the index of Failed \& Fragile States.

Beside these empirical investigations, Besley and Persson (2011) propose a theoretical framework to understand how fragility can hamper development and growth. Their theory highlights how a state may become fragile in situations of external or internal conflict, high political instability, and heavy economic distortions, and how fragility may in turn lead to poverty traps.

While the above contributions focus on the direct link between fragility and development, others have looked at its indirect influence through aid allocation. Since the condition of fragility is a crucial determinant of the amount of aid a country receives from international organizations, growth can be affected by fragility also through this channel. The interaction between aid and fragility is addressed in a number of studies, none of which is specifically focused on Africa. However, given the preponderant 
role played by African countries among fragile ones, their results are still useful to the present perspective. Burnside and Dollar (2000) provide evidence that aid is most effective in developing countries with sound institutions and policies. However, this conclusion is questioned on several grounds by Hansen and Tarp (2001), Dalgaard et al. (2004), and Rajan and Subramanian (2008). McGillivray and Feeny (2008) study the growth impact of aid in a world sample of fragile countries and find that it depends on the relative degree of fragility. Chauvet e Collier (2008) analyze the preconditions for sustained policy turnarounds in failing states and show that aid matters, but its effect depends on its kind (e.g., financial aid vs. technical assistance).

As emphasized by the theory proposed by Besley and Persson (2011), fragility is closely associated with conflict. Therefore, the literature that has evaluated the growth impact of conflict is also relevant. Examples within this stream include Collier and Hoeffler $(1998,2002)$, who search for the economic causes of conflict and then establish that Africa is indeed more vulnerable to it, because of its poverty; Blanton et al. (2001), who focus on the relationship between colonial domination and post-colonial ethnic conflict in Africa; and Bleaney and Dimico (2011), who distinguish between the correlates of the probability of onset of civil war and the probability of its continuation.

To conclude, the introduction of the broad concept of fragility, which reflects a complex combination of the dysfunctions that are typical of several African countries, has stimulated renewed interest for research on the deep roots of development in the region. At the same time, however, a clear impact of fragility on economic outcomes has proved hard to assess, partly because of the different definitions employed and probably also because of its potential endogeneity. 


\section{Slavery}

Another recent research line that has extended the perspective in a promising direction has focused on the long term impact of the African slave trades not only for Africa, but also for the recipient countries. This line of research is closely related to the previous ones since it emphasizes the role of historical factors and evaluates how their influence on economic outcomes may run through institutions. Nunn (2008a) first looks at the long term effects of Africa's slave trades on Africa itself. On the basis of shipping records and historical documents, he constructs measures of the number of slaves exported from each country in Africa in each century between 1400 and 1900 and finds a robust negative relationship between the number of slaves exported and current economic performance. Thus, the African countries that are the poorest today are the ones from which the most slaves were taken, even after accounting for the possibility of selection into the slave trades. Moreover, the paper indicates that the procurement of slaves results in subsequent state fragility and ethnic fractionalization.

The spillover of Africa's slave trades on the economic performances of the receiving countries is the theme developed by Engerman and Sokoloff (1997, 2002), on the basis of historical evidence they provide for the New World. Their influencial hypothesis can be summarized as follows. They first argue that factor endowments (climate, soil, crops, etc.) determined the suitability and hence the adoption of plantation slavery. In turn the use of slave labor caused extreme economic inequality which shaped the evolution of local institutions (including voting rights, the taxation system, and educational policy) in a way that hampered long term economic development. With the goal of testing Engerman and Sokoloff's hypothesis, Nunn (2008b) examines the relationship among slavery, inequality and economic development for a sample of 29 American countries and finds that the fraction of slaves over population in 1750 is indeed negatively correlated with per capita income in 2000. A similar negative 
relationship emerges for slave use, in each decade between 1790 and 1860, across states and counties within the U.S., although no evidence is found that this relationship is driven by large scale plantation slavery, i.e., by factor endowments. For the U.S. case, Nunn (2008b) also tests whether inequality is the channel through which slavery manifests itself on underdevelopment. The findings are once again mixed since, while it is true that slavery in 1860 is positively associated with contemporaneous land inequality, land inequality in 1860 is not correlated with income in 2000. Overall, these results confirm that slavery was detrimental for economic development, even though they question both the link between slavery and factor endowments and the role of inequality as the channel of transmission between slavery and current development. A closer look at the U.S. is taken by Bertocchi and Dimico (2010), who find that the negative influence of the slave share on current income is actually not robust to the inclusion of geographic controls which capture structural differences among regions, and even turns positive when state fixed effects are included. On the other hand, they find a negative impact of a dummy for slave states which, rather than the intensity of slave use, should rather reflect institutional differences, possibly linked to the Black Codes and the Jim Crow Laws. Moreover, they find that slavery has a positive and robust effect on current income inequality, i.e., those U.S. counties that displayed a higher share of slaves over population are not necessarily poorer, but more unequal, in the present day. They also show that the impact of slave use on current income inequality runs through racial inequality and that the channel of transmission from slavery to inequality is human capital accumulation. In other words, current inequality is primarily influenced by slavery through the unequal educational attainment of blacks and whites. Finally, for a sample of Mississippi counties, Bertocchi and Dimico (2011) analyze the link between slavery and political institutions and show that the former, rather than de jure provisions such as poll taxes and literacy tests, is the main driver of blacks' restricted suffrage at the end of the nineteenth century. Consistently, race and the legacy of slavery, 
rather than suffrage, emerge as the main determinants of a broad set of indicators capturing multiple aspects of current development.

A provisional conclusion I can draw from the above findings is that, despite the fact that the Engerman and Sokoloff's hypothesis is only partially supported, across different samples and specifications, still there is evidence that Africa's slave trades had a long lasting influence not only on Africa but also on the countries that used Africa as a source of slave labor.

\section{Conclusion}

The scope of this essay was to reconstruct the main steps along the path leading to the discovery of the determinants of growth in Africa, taking into account subsequent waves of a large literature which initiated from standard Solowian factors and ended up enclosing a wide array of additional considerations. While this literature had a broader scope, to account for the case of Africa was one of its main challenges. With the words of Easterly (2002), I can conclude that, in and out of Africa, the quest for growth has indeed been quite an elusive one. The list of proposed determinants of growth, or lack of it, has included, in order of appearance, physical capital, demographics, human capital, macroeconomic policies, geography, ethnic division, disease, and a large variety of historical and institutional factors. Fragility, a complex mix of dysfunctions, has been the latest newcomer to this list. Accounting for Africa's slave trades has allowed to broaden the perspective to growth spillovers even outside Africa itself. While some progress has been achieved, many questions are still open. While the list of potential growth correlates may not be exhausted yet, at least part of the responsibility for the absence of definite answers may actually fall not on lack of imagination about additional hypotheses, but on the underlying growth regressions approach. The latter certainly has its limits even after the 
advancements obtained through more sophisticated techniques including instrumental variables and panel estimation. Still, as acknowledged in a critical essay by Wacziarg (2002), despite their trouble in identifying causal links and the lack of robustness of their results, growth regressions have represented a first step toward a deeper understanding of what may underlie simple empirical correlations based on reduced forms. Durlauf et al. (2005) also recognize that most of the growth literature has simply attempted to investigate whether or not particular hypotheses can find any support in the data and to highlight systematic patterns. This approach, however, fails to capture the underlying channels of transmission. In order to establish causation, the estimated parameters must correspond to precisely identified links within a coherent framework derived from economic theory. Consider, for instance, the relationship between slavery and development. Even if it exhibited a robust statistical correlation, which is actually not the case, in order to understand its economic significance we would need a theory justifying the underlying mechanisms at work. In other words, why should past slavery still matter today? Because it reflects geography and initial factor endowments, because it shaped human capital accumulation in an unequal fashion, or else because it promoted divisive political institutions? To conclude, structural models based on rigorous theoretical predictions are the next - harder - step for future research on the empirics of growth. 


\section{References}

Acemoglu, D., Johnson, S., Robinson, J.A., 2004. Institutions as the Fundamental Cause of Long-run Growth. Ch. 6. In Aghion, P., Durlauf, S. (Eds.), Handbook of Economic Growth. North-Holland. Amsterdam. 385-472.

Acemoglu, D., Johnson, S., Robinson, J.A., 2001. The Colonial Origins of Comparative Development: An Empirical Investigation. American Economic Review 91, 1369-1401.

Alam, M.S., 1994. Colonialism, Decolonization and Growth Rates: Theory and Empirical Evidence. Cambridge Journal of Economics 18, 235-257.

Baliamoune-Lutz, M., 2009. Institutions, Trade, and Social Cohesion in Fragile States: Implications for Policy Conditionality and Aid Allocation. Journal of Policy Modeling 31, 877-890.

Barro, R.J., 1999. Determinants of Democracy. Journal of Political Economy 107, S158-S183.

Barro, R.J., 1991. Economic Growth in a Cross Section of Countries. Quarterly Journal of Economics 106, 407-444.

Bertocchi, G., 2006. Growth, History and Institutions. In Salvadori, N. (Ed.), Economic Growth and Distribution: On the Nature and Causes of the Wealth of Nations. Edward Elgar Publishing. Cheltenham. 331-349. 
Bertocchi, G., 1994. Colonialism in the Theory of Growth. Brown University Working Paper No. 9414.

Bertocchi, G., Canova, F., 2002. Did Colonization Matter for Growth? An Empirical Exploration into the Historical Causes of Africa’s Underdevelopment. European Economic Review 46, 1851-1871.

Bertocchi, G., Dimico, A., 2011. Race v. Suffrage: The Determinants of Development in Mississippi. Working Paper. University of Modena.

Bertocchi, G., Dimico A., 2010. Slavery, Education, and Inequality. CEPR Discussion Paper No. 8073.

Bertocchi, G., Guerzoni, A., 2011. The Fragile Definition of State Fragility. Rivista Italiana degli Economisti 16, 337-354.

Bertocchi, G., Guerzoni, A., 2010. Growth, History, or Institutions: What Explains State Fragility in Sub-Saharan Africa? CEPR Discussion Paper No. 7745.

Besley, T.J., Persson, T., 2011. Fragile States and Development Policy. Journal of the European Economic Association, forthcoming.

Blanton, R., Mason, T.D., Athow, B., 2001. Colonial Style and Post-Colonial Ethnic Conflict in Africa. Journal of Peace Research 38, 473-491. 
Bleaney, M., Dimico, A., 2011. How Different are the Correlates of Onset and Continuation of Civil Wars? Journal of Peace Research 48, 145-155.

Bockstette, V., Chanda, A., Putterman, L., 2002. States and Markets: The Advantage of an Early Start. Journal of Economic Growth 7, 347-369.

Burnside, C., Dollar, D., 2000. Aid, Policies and Growth. American Economic Review 90, 847-868.

Carment, D., Samy, Y., Prest, S., 2008. Determinants of State Fragility and Implications for Aid Allocation: An Assessment Based on the Country Indicators for Foreign Policy Project. Conflict Management and Peace Science 25, 349-373.

Chauvet, L., Collier, P., 2008. What are the Preconditions for Turnarounds in Failing States? Conflict Management and Peace Science 25, 332-348.

Collier, P., Hoeffler, A., 2002. On the Incidence of Civil War in Africa. Journal of Conflict Resolution 46, 13-28.

Collier, P., Hoeffler, A., 1998. On Economic Causes of Civil War. Oxford Economic Papers 50, 563573.

Dalgaard, C.-J., Hansen, H., Tarp, F., 2004. On The Empirics of Foreign Aid and Growth. Economic Journal 114, F191-F216. 
Durlauf, S.N., Johnson, P.A., Temple, J.R.W., 2005. Growth Econometrics. In Aghion, P., Durlauf, S.N. (Eds.). Handbook of Economic Growth, Volume 1A. North-Holland. Amsterdam. 555-677.

Easterly, W., 2002. The Elusive Quest for Growth: Economists' Adventures and Misadventures in the Tropics. MIT Press. Cambridge, MA.

Easterly, W., Levine, R., 1997. Africa’s Growth Tragedy: Policies and Ethnic Divisions. Quarterly Journal of Economics 112, 1203-1250.

Engerman, S.L., Sokoloff, K.L., 1997. Factor Endowments, Institutions, and Differential Paths of Growth Among New World Economies: A View from Economic Historians of the United States. In Harber, S. (Ed.). How Latin America Fell Behind. Stanford University Press. Stanford, CA. 260-304.

Engerman, S.L., Sokoloff, K.L., 2002. Factor Endowments, Inequality, and Paths of Development Among New World Economies. Economía 3, 41-88.

European Report on Development, 2009. Overcoming Fragility in Africa. Robert Schuman Centre for Advanced Studies. European University Institute. San Domenico di Fiesole.

Fenske, J., 2010. Institutions in African History and Development: A Review Essay, MPRA Paper No. 23120 
Fosu, A.K., 2009. Understanding the African Growth Record: The Importance of Policy Syndromes and Governance. UNU-WIDER Discussion Paper No. 2009/02.

Fosu, A.K., O’Connell, S., 2006. Explaining African Economic Growth: The Role of Anti-Growth Syndromes. In Bourguignon, F., Pleskovic, B. (Eds.). Annual Bank Conference on Development Economics (ABCDE). World Bank. Washington, DC. 31-66.

Galor, O., 2011. Unified Growth Theory. Princeton University Press, Princeton, NJ.

Gennaioli, N., Rainer, I., 2007. The Modern Impact of Precolonial Centralization in Africa. Journal of Economic Growth 12, 185-234.

Government and Social Development Resource Centre, 2010. Topic Guide on Fragile States. University of Birmingham.

Grier, R.M., 1999. Colonial Legacies and Economic Growth. Public Choice 98, 317-335.

Grossman, H.I., Iyigun, M., 1995. The Profitability of Colonial Investment. Economics and Politics 7, 229-242.

Hansen, H., Tarp, F., 2001. Aid and Growth Regressions. Journal of Development Economics 64, 547570. 
Henderson, V., Storeygard, A., Weil, D.N., 2010, Measuring Economic Growth from Outer Space. American Economic Review, forthcoming.

Huillery, E., 2009. History Matters: The Long-Term Impact of Colonial Public Investments in French West Africa. American Economic Journal: Applied Economics 1, 176-215.

Herbst, J., 2000. States and Power in Africa: Comparative Lessons in Authority and Control. Princeton University Press. Princeton, NJ.

La Porta, R., Lopez-de-Silanes, F., Shleifer, A., Vishny, R.W., 1998. Law and Finance. Journal of Political Economy 106, 1113-1155.

Lucas, R.E., jr., 1990. Why Doesn’t Capital Flow from Rich to Poor Countries? American Economic Review Papers and Proceedings 80, 92-96.

Lucas, R.E., jr., 1988. On the Mechanics of Economic Development. Journal of Monetary Economics 22, 3-32.

Maddison, A., 2007. Contours of the World Economy, 1-2030 AD: Essays in Macroeconomic History. Oxford University Press, Oxford.

McGillivray, M., Feeny, S., 2008. Aid and Growth in Fragile States. UNU-WIDER Research Paper No. 2008/3. 
Michalopoulos, S., Papaioannou, E., 2010. Divide and Rule or the Rule of the Divided? Evidence from Africa. CEPR Discussion Paper No. 8088.

North, D. C., 1981. Structure and Change in Economic History. W.W. Norton \& Co. New York, NY.

Nunn, N., 2009. The Importance of History for Economic Development. Annual Review of Economics 1, 65-92.

Nunn, N., 2008a. The Long-Term Effects of Africa’s Slave Trades. Quarterly Journal of Economics 123, 139-176.

Nunn, N., 2008b. Slavery, Inequality, and Economic Development in the Americas: An Examination of the Engerman-Sokoloff Hypothesis. In Helpman, E. (Ed.). Institutions and Economic Performance. Harvard University Press. Cambridge, MA. 48-180.

Nunn, N., 2007. Historical Legacies: A Model Linking Africa’s Past to Its Current Underdevelopment. Journal of Development Economics 83, 157-175.

Nunn, N., Puga, D., 2010. Ruggedness: The Blessing of Bad Geography in Africa. Review of Economics and Statistics, forthcoming.

Rajan, R.G., Subramanian, A., 2008. Aid and Growth: What Does the Cross-Country Evidence Really Show? Review of Economics and Statistics 90, 643-665. 
Rodrik, D., 1999. Trade Policy and Economic Performance in Sub-Saharan Africa. Expert Group on Development Issues. Almqvist and Wiksell International, Stockholm.

Romer, P.M., 1986. Increasing Returns and Long-Run Growth, Journal of Political Economy 94, 100237.

Sachs, J.D., Warner, A.M., 1997. Sources of Slow Growth in African Economies. Journal of African Economies 6, 335-376.

Sala-i-Martin, X., Pinkovskiy, M., Fargas, R.T., 2010. African Poverty is Falling... Much Faster Than You Think! NBER Working Paper No. 15775.

Schmidt-Hebbel, K., 1996. Fiscal Adjustment and Growth: In and Out of Africa. Journal of African Economies 5 (Suppl. Part I), 7-59.

Solow, R.M., 1956. A Contribution to the Theory of Economic Growth. Quarterly Journal of Economics 70, 65-94.

Wacziarg, R., 2002. Review of Easterly's The Elusive Quest for Growth. Journal of Economic Literature 40, 907-918.

World Bank, 2011. World Development Report 2011: Conflict, Security, and Development. World Bank. Washington, DC. 
Young, A., 2010. The African Growth Miracle. Working Paper, London School of Economics. 